\title{
Human displacement and social recognition: the working conditions and relations of refugees and displaced people in Brazil
}

\author{
JOSÉ HeNRIQUE de FARIA 12 \\ Elaine CRISTINA SCHMITT RAgNINI ${ }^{3}$ \\ CAMILA BRÜNING ${ }^{3}$
}

\author{
${ }^{1}$ Universidade Federal do Paraná / Programa de Pós-Graduação em Administração, Curitiba - PR, Brasil \\ 2 Universidade TeCnológica Federal do Paraná / Programa de Pós-GraduaçÃo em Administração, Curitiba - PR, Brasil \\ 3 Universidade Federal do Paraná / Departamento de Psicologia, Curitiba - PR, Brasil
}

\begin{abstract}
This research analyzes the process of inclusion and social recognition of migrants in a Brazilian city. The study presents a report of the demands from migrants in the context of a host project carried out at a Brazilian public university regarding their insertion in the world of work and in Brazilian higher education, highlighting their difficulties and expressions of suffering. Documentary research was used based on the analysis of qualitative data collected from about 300 interviews and over 1000 individual and group psychosocial consultations carried out with migrants in the city of Curitiba-PR. As a theoretical framework we adopted the category of "social recognition" proposed by Nancy Fraser (2008a) based on the debate with Axel Honneth (2009), and inspired by the category "struggle for recognition," by Hegel (2008). Results point to the precarious inclusion of migrants in the labor market, with evident social injustice and psychological suffering.
\end{abstract}

Keywords: Human displacement. Refugees. Migrants. Social recognition.

Deslocamento humano e reconhecimento social: relações e condições de trabalho de refugiados e migrantes no Brasil

\section{Resumo}

Esta pesquisa analisa o processo de inclusão e reconhecimento social de migrantes, de diferentes países em uma cidade brasileira, por meio de relato das demandas trazidas por eles no contexto de um projeto anfitrião realizado em uma universidade pública brasileira: (i) de sua inserção no mundo do trabalho, (ii) de sua inserção no ensino superior brasileiro, ressaltando as dificuldades e expressões de sofrimento apresentadas. O delineamento de pesquisa proposto é um estudo documental, a partir da análise de dados qualitativos coletados por cerca de 300 entrevistas e mais de 1000 consultas e atendimentos psicossociais (individuais e em grupo) realizadas com migrantes na cidade de Curitiba- PR. Como referencial teórico adotamos a categoria de "reconhecimento social", proposta Nancy Fraser (2008a) a partir do debate com Axel Honneth (2009), inspirada na categoria "luta pelo reconhecimento", exposta por Hegel (2008). Resultados apontam para a inclusão precária de migrantes no mundo do trabalho, evidenciando injustiça social e sofrimento psíquico desses sujeitos.

Palavras-chave: Deslocamento humano. Refugiados. Migrantes. Reconhecimento social.

\section{Desplazamiento humano y reconocimiento social: relaciones y condiciones de trabajo de refugiados y migrantes en Brasil}

\section{Resumen}

La investigación analiza el proceso de inclusión y reconocimiento social de migrantes de diferentes países en una ciudad brasileña, a través del relato de las cuestiones planteadas por ellos, en el contexto de un proyecto anfitrión llevado a cabo en una universidad pública brasileña, a cerca de: (i) su inserción en el mundo del trabajo, (ii) su inserción en la educación superior brasileña, destacando las dificultades y expresiones de sufrimiento presentadas. El diseño de investigación propuesto es un estudio documental, basado en el análisis de datos cualitativos recopilados en alrededor de 300 entrevistas y más de 1000 consultas psicosociales (individuales y grupales) realizadas con migrantes en la ciudad de Curitiba, PR. Como marco teórico, adoptamos la categoría de "reconocimiento social", propuesta por Nancy Fraser (2008a) a partir del debate con Axel Honneth (2009), inspirada en la categoría "lucha por el reconocimiento", expuesta por Hegel (2008). Los resultados indican la inclusión precaria de migrantes en el mundo del trabajo, lo que demuestra la injusticia social y al sufrimiento psicológico de estos sujetos.

Palabras clave: Desplazamiento humano. Refugiados. Migrantes. Reconocimiento social. 


\section{INTRODUCTION}

According to the United Nations (UN), we are experiencing the biggest humanitarian crisis since the creation of the UN in 1945. It is estimated that the number of migrants currently surpasses 272 million. According to data from The United Nations Refugee Agency (UNHCR), presented in the Global Trends report (2020), by the end of 2019 there were around 79.5 million people in the world who were forced to leave their countries of origin because of war, persecution, conflict or widespread violence. With regard to refugees, individuals who have suffered a deep fear of persecution in their homeland and are in foreign lands, it is estimated that there are globally about 29.6 million people in this condition, and another 4.2 million awaiting the outcome of their asylum claims. In Brazil, these requests totaled 80,057 in 2018 (Ministério da Justiça, 2019).

As a signatory to the 1951 UN Convention, and its 1967 Additional Protocol, as well as the 1984 Cartagena Treaty, Brazil proposes to grant protection and guarantee basic rights to foreigners residing in the country (Gediel \& Godoy, 2016). Additionally, with the New Law on Migrants (Lei $n^{\circ} 13.445,2017$ ), refugees and migrants now have the right to public health, protection and work on an equal basis with the national population (Lei no 13.445, 2017). However, it remains necessary to question what is the place that migrants ${ }^{1}$ occupy in work and other everyday relations in Brazil; that is, how immigrants are socially recognized in work relationships and in the process of insertion in daily life in Brazil.

Based on this questioning, the objective of this research is to analyze the process of inclusion and recognition of migrants from different origins (Haiti, Syria, Venezuela, several African countries, among others) in a Brazilian city, using the reports of the demands brought by them in the context of a host project carried out at a Brazilian public university concerning: (i) their insertion in the world of work, (ii) their insertion in Brazilian higher education, highlighting their difficulties and expressions of suffering.

The research design proposed here is a documentary analysis in which we analyzed the record of (i) about 300 interviews with migrants and refugees that were seeking reintegration into higher education at the Federal University of Paraná (UFPR) and/or that requested the revalidation of a diploma, and (ii) more than 1000 reports of psychosocial consultations (individual and group), both held between the years 2015 and 2019 with migrants and refugees in the city of Curitiba-PR. These interviews and consultations were conducted within the scope of an Outreach Project (also known in Brazil as University Extension, or Extension Project) of the Department of Psychology (DEPSI) ${ }^{2}$, by a research group in which one of the authors of this article participates. To reflect on the place that migrants and refugees have occupied in labor relations and in the process of insertion in daily life in Brazil, we adopted the theoretical category of "social recognition", adapted from Nancy Fraser (2008a) in her debate with Axel Honneth (2009) on the category (Fraser \& Honneth, 2003) "struggle for recognition", proposed by Hegel (2008). We start from the understanding that the centrality of work is one of the foundations of social recognition, as it includes workers in the productive process, and may reveal certain working conditions that institute "paid slavery" (Mészáros, 2002). From this theoretical basis, we discuss how the condition of being recognizedin a given social group does not imply its adherence to the economic, legal-political, social or cultural model that recognizes it.

\footnotetext{
${ }^{1}$ Following the proposed by Chueiri and Câmara (2010), in this work we use the concepts of "migrants", "refugees" and "displaced people" in a generic way. Our understanding is that what identifies and allows to include these concepts in the same category is the "displacement experience that marks them. And when we say 'marks' it's in a very concrete sense. The displaced bodies are marked precisely by the lack of identity and recognition" (Chueiri \& Câmara, 2010, pp. 160-161).

${ }^{2}$ This DEPSI Outreach Project is linked to the UFPR Program called Migration Policy and Brazilian University, signatory of the Sergio Vieira de Mello Chair, of the United Nations High Commissioner for Refugees- UNHCR, which aims to welcome and assist migrants who need to work and live in the new land. The Program is composed of Outreach Projects from 8 different courses: Letters, Law, Psychology, Sociology, Informatics, History, Medicine and Communication, in addition to partnerships with other institutions, composing a service network for this public. Here we analyze only the Psychology Outreach Project.
} 


\section{THEORETICAL FRAMEWORK}

Social recognition is essential for understanding the situation of migrants and refugees both in the world of work and in everyday relationships. The category "struggle for recognition", proposed by Hegel (2008) since the so-called "writings of Jena", is being updated and reintroduced both in the philosophical debate and in the social sciences to explain the origins of social conflicts. The theme of recognition has occupied a prominent place in philosophy since Hegel (2008), when interpreting conflict as a mechanism for social transformation in the construction of a society in which social relations are more structured, introduces the category of respect and intersubjective recognition as the engine of these conflicts.

The subject only exists as long as it is recognized by the other. In this regard, the works of Lacan (1966) and Enriquez (1974) are particularly important. Lacan (1966) is faithful to the Hegelian dialectic, especially in his lecture on the mirror stage as the creator of the function of the Self, in which the whole individual dramatic is centered in the "desire of the other".

This Hegelian analytical category, however, was taken up with more emphasis by the third generation of the Frankfurt School with the philosopher and sociologist Axel Honneth (2009), who postulates an empirical investigation in the field of the sociology of recognition; by the Canadian political philosopher Charles Taylor $(2000,2005)$, who seeks in historical philosophy the bases of social recognition as the fundamental link between subjects; and by the American political scientist Nancy Fraser (Fraser \& Honneth, 2003), who is dedicated to the study of social movements and political conflicts.

Fraser (2008a, 2008b), especially, insists that social conflicts cannot be explained only from the perspective of struggle for social recognition, but also by the struggle for the redistribution of the material wealth produced and for equal representation in decision-making spheres. For Fraser, these three forms correspond to three dimensions of justice: cultural (recognition), economic (redistribution), and political (representation).

This struggle for social recognition takes place within the dominant political system, and may even be contrary to it, either as resistance or as opposition, in aiming to overcome it. The argument developed here agrees with the one proposed by Fraser (2008a), according to which collective subjects struggle for social recognition as a form of full integration into society as equal subjects. Thus, the demands expressed by different social groups aiming at the equality of rights and life conditions point to the decline of the class political identity (decline of democracy) and of the political imaginary for social justice. In the specific case of migrants, this proposition is expressed in the form of a right in the New Law for Migrants (Lei $\left.n^{\circ} 13.445,2017\right)$ when referring to the "condition of equality" of the immigrant "with the population" in Brazil (Lei n 13.445, 2017).

This decline has important political consequences, since instead of class struggle there are now several unrelated groups that fight for their legal-political, economic and ideological interests, as well as for cultural domination. This implies a rupture between economic and cultural policy and social policy, the latter being subsumed to the former (Fraser, 1997). Everything would happen as if the fight against racism, prejudice and discrimination were merely cultural and were not related with the redistribution of material wealth, social recognition, equal representation and self-realization (Faria, 2017).

Fraser (1997) suggests that it is not a matter of overcoming the traditional division of classes, including issues such as gender, prejudice, unemployment, urban social rights, education, public health, security, housing, urban and rural infrastructure, among others. It is within the class division that these questions lie, and that includes the problem of migrants and refugees. The centrality of social struggles shifts from the class conflict historically led by workers' movements, establishing a new confrontation agenda. This does not imply the disappearance of social classes and fundamental conflicts that exist in the capitalist mode of production, but it does indicate that the struggles reach other dimensions that need to be understood from a critical perspective.

Honneth (1991), inspired by Hegel, treats recognition as a social struggle in which conflicts are attributed to "moral impulses" and not to reasons of self-preservation as defended by Hobbes and Machiavelli. Honneth (2007) seeks to update Hegel's philosophy of law, which is based on the development of the theme of recognition. When considering, then, the "struggle for recognition" as an analytical category, Honneth (1991) tries to integrate Foucault's theory of power to Habermas's theory of communicative action, understanding that they are capable of filling the "sociological deficit" from Adorno's and Horkheimer's theories. Honneth's (1991) intention is to define a conceptual framework that allows analyzing the "structures of social domination" and because neither Foucauldian theories, with their normative deficiencies, nor Habermas' theories, 
with their level of abstraction, fulfill the requirements of their definition, Honneth rescues Hegel's theory. Honneth (2009), when exposing the three theses of Hegel's model, explains that the Hegelian concept has a metaphysical tradition, a "merely speculative foundation" (Honneth, 2009, p. 121), which is why he will look in Mead's social psychology for the empirical basis that, he argues, allows "to translate the Hegelian theory of intersubjectivity into a post-metaphysical theoretical language" (Honneth, 2009, p. 123).

Despite Honneth's attempt to give his proposal an empirical inflection, the degree of abstraction that takes over his analysis places him on the same metaphysical level that he criticizes in Hegel. The use of Mead does not solve the problem that Honneth poses reagarding empirical reasoning, precisely because the result of his elaboration is a typology of patterns of forms of intersubjective recognition: love, law and solidarity.

These patterns, as can be deduced from his own arguments (Honneth, 2009, pp. 276-279), are filled with uncertainties and speculation, be it when seeking in Winnicott's psychoanalysis the "tense balance between fusion and delimitation of the ego" to address of loving individuality without anguish; or when establishing a relationship of dependence between self-realization and the "social assumption of legally assured autonomy", or when he states that "the pattern of recognition of social solidarity [...] can only arise from common shared goals (which) are subject to normative limitations", that is, solidarity depends on normatively limited solidarity.

Nancy Fraser comes to the topic of social recognition precisely in the debate with Honneth (Fraser \& Honneth, 2003). Also starting from the discussion with Foucault and Habermas, Fraser criticizes both: Foucault for his rejection of normative standards that is, of rules that can establish directions or developments, which would prevent his criticism from resulting in an emancipatory political action; Habermas, among other criticisms, because it would hide relations of domination instead of revealing them.

The struggle for recognition, in Fraser's perspective (2008a, pp. 11-12) quickly became the paradigmatic form of undersatnding the political conflict in the twentieth century. The demands for recognizing differences make the struggles of social groups to be mobilized under the banner of nationality, ethnicity, race, gender and sexual option. In these conflicts, the identity of social groups supersedes class interests as the main means of political mobilization. Cultural domination supersedes exploitation as the fundamental injustice and cultural recognition takes the place of socio-economic redistribution as a measure of injustice and the objective of political struggle. The struggle for recognition, however, occurs in a world of exacerbated material inequality, which means that the challenge of developing a critical theory of society requires an understanding that justice must contemplate the articulation between economic redistribution, social recognition and political representation. For Fraser, therefore, a recognition policy that fails with regard to human rights, for example, is unacceptable even if it promotes social equality. It is precisely at this point where the confrontation between the three-dimensional concept and the conception centered on moral monism that resides the main controversy between, respectively, Fraser and Honneth (2003), which most closely concerns the present study.

The debates that followed Fraser's analysis led her to return to the theme of recognition in other studies (Fraser, 2000, 2002b), abandoning the first version in which recognition is treated according to an identity model to address it as status, not least because Fraser will introduce the issue of globalization in her considerations (Fraser, 2002a, 2004).

In the status model, dimensions relate to different aspects of the social order, so that recognition refers to the social status (status groups), while redistribution refers to the economic structure (property, market, labor, wealth). Although she introduced the issue of representation at the beginning of the debates (Fraser, 2002, 2004; Fraser \& Honneth, 2003), it is nevertheless in a more extensive analysis that Fraser (2008a) reviews her theories of recognition and redistribution and definitively introduces this third element to her reflection of critical theory. For Freaser, representation corresponds to the political dimension.

For Fraser, in the perspective of analytical pluralism, social recognition also contemplates the redistribution of the material wealth produced and political representation in decision-making processes, as these are irreducible dimensions of justice and must not be subordinated to a superior dimension, that of recognition (Fraser, 1997, 2008).

As Silva (2008, p. 118) notes, even though the theories of Fraser, Taylor and Honneth originated with the purpose of "articulating a common grammar for the social conflicts associated with the new social movements", it is Fraser who laments "the abandoning of socialist demands for social equality and replacing it with the policy of difference", a change that coincided with 
"the right-wing discourse against social rights". For Fraser (2000), the "identity model", which equates identity and recognition, is problematic not only theoretically, but politically, as it strengthens the reification of group identities, shifting the struggle for redistribution and representation.

The theory of recognition, although it is not a negation or abandonment of the historical class struggle, highlights the particularities of the struggles of social groups. This reference is important for understanding the issue that emerges from the migration process, questioning whether immigrants, from different social categories, in their manifestations, consider themselves as socially recognized subjects in the receiving country, regardless of the legal apparatus that express this guarantee.

\section{METHODOLOGICAL PROCEDURE}

In 2013, a group of professors from the Language Course at the Federal University of Paraná (UFPR) developed an Outreach Project based on the demands of the Curitiba City Hall and the Casa Latino Americana (CASLA). The proposal was to work on the teaching of Brazilian Portuguese as a host language for migrants and refugees (Barbosa \& Ruano, 2016). When teaching the language, teachers faced both the difficulties related to fundamental and labor rights, as well as the difficulties linked to the suffering and psychological trauma of this public. That was how, in 2014, the Department of Psychology (DEPSI) was asked to contribute to an answer to this demand for psychosocial care, constituting the Outreach Project whose documents we analyzed in this research.

The DEPSI Outreach Project has an annual participation of, on average, 20 students, 4 teachers and 4 psychologists. Its activities consist of: (i) reception and psychosocial care; (ii) clinical psychological care; (iii) guidelines and workshops for the insertion of migrants in the labor market and in the university; (iv) monitoring and assisting migrants studying at UFPR; (v) interviews for admission to UFPR and for the revalidation of diplomas; (vi) accompanying children of migrants who study Portuguese at UFPR; and (vii) monitoring and construction of the migration policy at the university and in the city. These activities take place under the supervision and guidance of UFPR faculty members. Students and volunteers are asked to report all their activities to their advisors in the form of reports and field diaries. In this way, all interviews and consultations carried out are transcribed. Despite the limitations of all statements regarding the mediation process between the exposure and the exposed reality, the transcription of the reports is confronted with the interviewees and assisted in a way that their content is faithful to the testimony. These documents are the sources of evidence analyzed in the present work.

The research design proposed here is, therefore, a documentary analysis (Godoy, 1995) based on reports of interviews, testimonies and psychosocial consultations, carried out within the scope of the aforementioned Outreach Project. In this research, we accessed the transcripts of nearly 300 semi-structured interviews conducted with migrants seeking re-entry into higher education at UFPR, and/or requesting revalidation of a diploma with exemption from the registration fee between the years 2015 and 2019, as well as the diaries and reports of more than 1000 psychosocial consultations (individual and group) carried out during this period.

The documents were analyzed using the content analysis technique: based on the documentary analysis in which records of concrete situations and the theoretical framework adopted here were found, we seeked to find the reported elements that allowed us to answer the question about whether and how migrants considered themselves socially recognized in work relationships and in the process of insertion in daily life in Brazil. The documents were submitted to analysis, therefore, from the thematic criterion of social recognition according to nuclear (or key) problems or propositions (Bardin, 1979).

The interest of the research was to verify how the process of inclusion and recognition of migrants from different origins (Haiti, Syria, Venezuela, several African countries, among others) occurs, using content analysis of the documented reports, in order to verify the insertion of the immigrants in the world of work, their insertion in higher education, from their account of the difficulties found in Brazil (specifically in the city of Curitiba - PR), and of the expressions of psychological suffering they manifest and the demands placed by them in the context of this Outreach Project. 
The relevance of this study and its originality are found in the fact that the interviews and psychosocial care were not directed from a pre-category, but emerged from the real situations experienced by immigrants in their daily lives. The issue of recognition appears in different expressions in the analyzed documents, in a way that the chosen category of analysis was able to later synthesize it properly. From these reports, we were able to identify that there was a recurring element in the statements and demands brought by the migrants, which was the search for social insertion through work and in the educational system. In this way, we highlight the theoretical category of the struggle for social recognition proposed by Nancy Fraser as an indicator of analysis of this process. In this sense we highlight that the practical and theoretical contribution of this research is broadening the understanding of the social phenomenon of migration and insertion of migrants in Brazil, as well as the development of the Theory of Recognition, applying it here to a new social field of analysis, that is, that of migration.

The results obtained through this documentary analysis allow us to identify several characteristics of the insertion of migrants who are in Curitiba-PR in the world of work and in higher education. We will discuss how these characteristics suggest that these immigrants are disqualified as subjects in a process of social non-recognition (Fraser, 2000, 2002a, 2002b, 2004).

\section{MIGRANT PROFILE}

Based on the analysis of interviews and field diaries of visits and activities carried out with migrants and refugees in DEPSI's outreach project, some characteristics of this population were identified: these are men and women migrants and refugees coming in greater numbers from Haiti; followed by African countries such as Guinea-Bissau, Congo and Benin; thirdly from Latin American countries, mainly from Venezuela; and finally, migrants and refugees from Syria. This is the general profile of the population studied, which does not mean that this is also the profile of migrants residing in Curitiba and Metropolitan Region (whose data are not officialy available).

The majority of people seeking re-entry, diploma revalidation and psychosocial care at UFPR are men. Regarding their age, those who seek psychosocial care vary from 4 to 67 years old, mainly seeking guidance on how to enroll their children in school, information for the organization of adult life and psychological assistance. The age of diploma revalidation applicants varies between 26 and 60 years, with the majority being between 30 and 40 years old, which indicates that they are professionals who already had a profession in the country of origin consistent with their academic background. Finally, the age of applicants for re-entry varies between 20 and 37 years, with the majority of them being under 25 years old, which is consistent with the age characteristic of the university populationin Brazil. It is interesting to note, however, that about $1 / 3$ of the interviewees are in an age category slightly above the profile of the university students in this institution, that is, between 26 and 30 years old (no difference in age profile was identified by nationality, or by gender of these migrants and refugees), and this difference in age may be one of the factors related to difficulties in integrating with fellow students, a complaint made by some migrants studying at the university.

As for coming to Brazil, these refugees and migrants arrived in the country from 5 months to 5 years ago, having left their countries of origin for different reasons: (i) economic situation, such as unemployment, financial problems, difficulties to cope with education costs and living costs; (ii) political situation, such as political persecution; (iii) violence in the country of origin, such as urban violence, insecurity in moving around the city, and homofobia; (iv) natural disasters; and in fewer cases, (v) reasons related to personal/family issues, such as the loss of family members (especially loss of family members who paid for family costs).

As for the reasons that migrants and refugees presented for havinhchosen to come specifically to Brazil, it was possible to identify, group and order seven explanations: (i) personal reception in the destination country: they chose Brazil, as they already had family members or friends residing in the country; in general, these family members or friends shared information about life, work, and study in Brazil, and/or acted in welcoming/receiving migrants on their arrival in the country; (ii) educational opportunity: they considered that in Brazil they would have the opportunity to study, given the possibility of free higher education; (iii) political regime: they saw Brazil as a democratic country; (iv) receptivity of migrants: they mention a migration policy facilitated in Brazil in relation to migrants from their country of origin; (v) language: they mentioned having chosen Brazil because it is a Portuguese-speaking country (mentioned by migrants from African countries who also speak Portuguese); (vi) location in relation to the country of origin: the geographical proximity of Brazil to the country of origin (mentioned by migrants from Latin American countries, regarding the convenience in reaching the country, returning to the country 
and/or bringing family members when possible); (vii) to have prior knowledge of the destination city: two migrants had already visited the city of Curitiba - PR and specifically liked the living conditions that the city offered.

It is possible to identify that several migrants passed through other countries before choosing to come to Brazil: they mentioned having lived previously in other host countries and, not having adapted, coming to Brazil as a second choice. The reasons commonly mentioned for non-adaptation are related to the perception that they were victims of racism and xenofobia, that is, reasons related to social non-recognition (Fraser, 2000).

In addition, it is possible to identify that coming specifically to Curitiba-PR was not an option in itself for this city, but something that "happened". There is the case of several migrants who passed through other Brazilian cities, such as Manaus, Cuiabá, Foz do Iguaçu and São Paulo before arriving in this city specifically. Those who went directly to the city were those who had family, friends or acquaintances and who felt most comfortable or welsomed. There was no relationship between the choice for Curitiba and possibilities for quality of life, housing, political and socioeconomic conditions and other expectations.

The migration process within the country is taking place: (i) on the initiative of migrants who are looking for work/study opportunities based on what they hear from other migrants who arrived in the city before them; (ii) on the initiative of companies that seek to hire migrants and refugees and recruit labor in cities that receive larger flows of migrants (such as from border regions). It is interesting to note that there are Human Resource Management consultancies specialized in intermediating this recruitment, as identified by Zeni and Filippim (2014); (iii) the presence of public policies with action at the Federal, State, Municipal level and partnership with private organizations for the integration and employment of migrants. This situation is observed in specific reports, such as among Haitian migrants who arrived in Curitiba in 2010 and were employed in civil construction, mainly in the construction site at the Football Stadium of Club Athlético Paranaense for the 2014 Soccer World Cup.

\section{RESULTS AND ANALYSIS: THE LACK OF SOCIAL RECOGNITION AND THE DISQUALIFICATION OF SUBJECTS AS SUBJECTS}

The analyzed reports indicate that the social fabric of non-recognition (Fraser, 2000, 2002a, 2002b) is perceived by individuals as a set of conditions that govern their lives, which are strictly ordered by rules and norms mediated by language. The reports point to the conformity to living conditions, which are as they are, guiding the confrontations. These research findings corroborate to other studies that show the reality of the reception, protection and integration of migrants and refugees in Brazil: an absence of effective action by the government that leaves a place that is being occupied by other organizations of interest, in the Brazilian case, companies (often with irregular practices that lead to the exploitation of the work of these migrants), churches, voluntary associations and universities (Machado, Barros \& Martins-Borges, 2019; Moreira, 2014; Moulin, 2011). There are reports, that, for example, experienced Haitian engineers are hired (in outsourced mode) as masters builders. Therefore, without recognition of their social status.

According to Enriquez (1974, p. 54), as one is led to look for their place in the social structure, "everything happens as if life were strictly formalized and could be apprehended and controlled". In this sense, the individual is not the creator of his relationships, that is, reality is given to him as something ready, without the capacity for transformation or real appropriation. According to the report of the migrants, the lack of social recognition at the same time that it affects the process of insertion as subjects of law, presents itself as a naturalized difficulty, for the solution of which is sufficient an acceptable measure to the condition of foreigner.

The documents analyzed in the scope of the Outreach Project, revealed reports of several difficulties that migrants and refugees pointed out in terms of social recognition (non-recognition), among which we can highlight: (i) financial difficulties, to support themselves, pay rent, send money to the family that stayed in the country of origin, pay for studies. There are reports of "going days without eating", "depending on help", "depending on charity"; related to these is the difficulty of 
(ii) not getting a job or not getting good jobs; next, the (iii) difficulties related to the Portuguese language / communication in Brazil are mentioned in greater volume; (iv) socialization difficulties, such as reports of being "misunderstood by people", "the way people treat them", "people in Curitiba being very closed", difficulties in making friends with locals, "not having Brazilian friends", having friends only of their own nationality, difficulty in having good relations with classmates (at the university, for example, they mention that: "they don't want to do group assignement with me"), difficulty in having good relations with co-workers and bosses (for example: "I don't talk to anyone, I do my job and that's it"; "I prefer to stay with my friends (same nationality) at work, Brazilians are difficult"), they also mention the occurrence of racism (racial injury) and xenophobia (example: "They say I should go back to my country"). (v) Being away from family, a situation that they relate to homesickness, sadness, hope of "being able to bring their family members close to them", also of returning to their country of origin. Finally, to a lesser extent, reports of difficulties in adapting to (vi) culture (mentioned: customs and food) and (vii) to the climate.

These reports point to an important issue in the process of social recognition, which is the social identification and idealization of the conditions for the acceptance and insertion of migrants as social subjects, wich they really are. However, in this idealization, the concrete conditions of capitalist relations of production are abstracted in favor of the immediate (Fraser, 2000). These identification and idealization processes occur within the specific scope of the reported difficulties. For the construction of a common project, in which migrants must be inserted as a constitutive part, it is necessary that representations are not only intellectually thought and effectively realized, but affectively felt. This feeling of inclusion is not expressed, prevailing that of a foreigner who hopes to obtain a "favor" from the host country. "It's not just about wanting collectively; it's about feeling collectively" (Lévy, Nicolaii, Enriquez \& Dubost, 1994, p. 57). However, the source of group behavior can only emerge if linked to an idealization system, the result of conscious and unconscious processes. The idealization process is what gives "consistency, vigor and exceptional aura" to both the project and the individuals, enabling them to share the same illusion (Lévy et al., 1994, p. 57). The reports do not indicate a collective project that allows the sharing of a common social bond. Migrants are faced, simultaneously, with the non-recognition of the society in which they intend to enter and with the non-recognition that they have a common bond.

\section{Insertion in the world of work}

As for their insertion in the world of work, it was possible to identify that only a minority of these migrants and refugees is currently working, being the difficulty of finding jobs, work or a way to support themselves the main difficulty reported by them. Among those who are working (i) most report to be carrying out informal activities, with incomes of up to one minimum wage; (ii) some report carrying out formal jobs sporadically, by contract with a predetermined period, mainly in civil construction. There are also reports of (iii) part-time formal work, mainly in operating and cleaning positions in the industry; (iv) housework, such as cleaning, especially in the case of women. It appears, therefore, that the situation of insertion in the world of work of these migrants is that of precarious and low-paid work. Professional training and experience of migrants is not taken into account in hiring processes. The reports indicate that migrants are considered, in the selection processes, as being in a lower position in the social hierarchy.

Migrants who are better off (the minority of cases) have a full-time formal job with a salary that ranges from minimum wage to $R \$ 2,000.00$. These are jobs mostly in the service sector. Most migrants in this employment condition speak Portuguese with no or little difficulty, are "white" (Syrians and Latin Americans), have training/education that overqualifies them for their position, as well as experience in another area of activity, generally of a social status that is more vallued than the one they are performing. In these cases the situation of deprofessionalization of these migrants is evidenced. Every social organization has a structure of values and norms that condition its members to a certain way of apprehending the world and guiding their conduct. What the reports show is that the social relations in which migrants are inserted intend to be understood as a microsociety par excellence and consequently crossed by the same problems that characterize the social bond. The analysis suggests that migrants have an expectation of establishing links not only social and material, but, above all, affective and imaginary. These links are at the basis of assertive recognition. In this sense, the adhesion of these migrants to the social project (work, university education, social insertion, etc.) 
may be the result of two types of processes that, in reality, are combined and that are the result of the production of an imaginary system: (i) narcissistic desires for recognition, ensuring protection against breach of identity, which prevents autonomous and creative production; (ii) that which Lévy et al. (1994) call "motor imaginary", which favors creativity and is capable of living with changes and ruptures. This imaginary includes spontaneity, experimentation and critical thinking. In these cases, every recognition project focuses on insertion.

\section{Insertion in higher education}

This insertion process is evident in the search for inclusion by these migrants in Brazilian higher education. An important part of the reports is that of migrants seeking revalidation of a diploma from UFPR or requesting admission to the university to resume studies at the higher education level. This situation does not reflect the condition of migrants in general, as those who are not in this condition have less reason to seek contact with the university.

Regarding the attempt to revalidate the diploma, it is initially worth noting that the process of revalidating an undergraduate diploma obtained abroad is expensive for a migrant who is in Brazil. In 2019, the registration fee for the revalidation of a diploma by the Carolina Bori Platform at UFPR was R\$1,500.00. By Resolution 02/16-CEPE-UFPR, it is possible to request a special process of revalidation of diplomas for migrants and refugees by paying a fee of $R \$ 550.00$, or requesting an exemption from the registration fee, once the condition of social vulnerability and migrant's economic status is proven. The majority of migrants who request exemption from the tax have an average remuneration of one minimum wage, making this investment unfeasible. This charge shows that the process of social recognition of migrants and refugees by the university is restrictive, although accessible, especially in the case of a public and free institution. Without the revalidation of the diploma, in Brazil, professionals cannot exercise their original profession, since professional councils (which constitute professional corporations) do not guarantee their professional registration. The process of revalidating diplomas is not only formal and subject to bureaucratic norms and rituals, but also slow, condemning migrants and refugees to a perverse time of waiting and uncertainty.

Another obstacle is the evaluation process which consists of an objective test of high difficulty, a practical test and an interview, all conducted in Portuguese. Rosa (2018) reflects on the entry of refugee students in Brazilian higher education and shows how linguistic insertion is a condition of hospitality for these migrants.

Rosa (2018) highlights the role played by the Portuguese language as the main constraint that, at the same time, makes it possible and impossible for migrants to access the Brazilian university. In her findings, Rosa (2018) points out that the difficulties non-portuguese-speakers face when seeking admission to public universities include the lack of information, since the programs are not disclosed in detail even on the official pages of the universties that propose them, as well as the facts that they are publicized only in Portuguese. Here we complement with another dificulty, the fact that the selection process is carried out exclusively in Portuguese.

The Portuguese language is not only a barrier to access to higher education, but points to the exclusive, regulatory and restrictive character of institutional discourse; the non-recognition of the migrant as a subject of law, but as a foreigner.

The evaluation process, is of responsibility of each department, which receives only general guidelines from the university for its preparation and, therefore, acts according to its own understanding and, sometimes, according to its own agenda when establishing the content and the degree of difficulty of the evaluations. There is no social recognition policy with specific guidelines.

We found, from the documents, that the rate of approval for diploma approval revalidations is less than $10 \%$ of those enrolled. The rigor and the claim that the Brazilian (and local) disciplinary structure is the ideal model of professional training implies the failure of immigrants to exercise their profession in Brazil, culminating in an extensive period of disqualified work from the point of view of academic training and a feeling of frustration and withdrawal from trying to exercise their profession of choice.

However, even in the cases of migrants who have revalidated their diploma and are able to exercise their profession in Brazil, they report that the beginning of professional activity was difficult; they received low remuneration and had to start at the 
base of their career. It is worth mentioning the case of dentists, engineers and administrators who, even after 3 years of revalidated diploma, do not obtain a remuneration consistent with their professional qualification or previous experience, that is, they are not socially recognized. This failure, in some cases, culminates in the decision to migrate from Brazil.

Another concrete element of (non) social recognition is the search for re-entry into the university: everyone who sought re-entry applied for the same course they were studying in their country of origin, or in a course that they considered as close as possible to what they were studying among those offered that year by UFPR. As an example: there are interviewees who were studying Nursing and trying to re-enter in Pharmacy; studied Airplane Mechanics and tried Mechanical Engineering, studied Medicine and tried Biomedicine, studied Social Anthropology and tried History, etc. It is interesting to point out how in most cases there is a re-option for a course that has a lower status of social recognition than what they were studying in their country of origin, again here characterizing a condition of deprofessionalization of these migrants. Often, too, this is because the required course does not exist at UFPR or has no remaining vacancies for re-entry. However, in courses called high demand, there is a tendency to lower recognition.

Most migrants a report attempting to re-enter for the first time, but there are those who have been waiting to try for years before the university offered an option to enter a course of interest (similar to what they were already studying). It is also common to report passages through other educational institutions in Brazil before attempting to re-enter at UFPR. Among these passages in other educational institutions, the following stand out (i) passages in private higher education institutions in the same city, cases in which the interviewees interrupted the course due to financial difficulties; (ii) experiences at other public higher education institutions in Brazil (ex: Pro-Haiti program at UNILA. They present as motivation for trying to trade universities the fact that they consider "the conditions of the course to be bad", "not having had good relations at the other university"). There are also reports of migrants who made previous unsuccessful attempts to re-enter public universities in other Brazilian states ("did not pass the test").

It appears that the process of re-entry into the university is seen as difficult by migrants. In addition to the publci notices being published in Portuguese, information on the specifics of the courses is dispersed, the offer of places varies from year to year and the tests require more knowledge about disciplinary specificities than professional.

Once they manage to re-enter the university, some difficulties they face during the course are identified: (i) difficulty in understanding academic language; (ii) difficulty in relationships with colleagues and teachers; (iii) difficulties due to economic issues (commute, food, materials for studies); (iv) discrimination, racism and xenophobia. Elements that are indicative of a fundamental (non) social recognition (Fraser, 2000, 2002a, 2002b).

On a more positive note, the analysis of the documents allows to identify manifestations on the part of migrants of "privilege to study at a public university", of the "feeling of being included in a Brazilian social and cultural environment", of resumption of life projects and of "hope about life" and the future. It can be argued that insertion into the university environment, even though it is a source of exclusion, at the same time rescues for migrants a possibility of social recognition, that is, of a recognition process that projects the condition of continuing to desire a place in the relationship with the other.

At the psychosocial level of recognition, there is an explanation for the movement of bonding between concrete subjects, which is essential for the recognition of common interests and an essential condition for social and work relations. By presenting a dialectical dynamic, in which antagonistic poles (pleasure and anguish, alienation and recognition, repetition and overcoming) are at stake, it is understood that this level of analysis represents an important part for the understanding of social recognition relationships. 


\section{CONCLUSIONS}

According to the theoretical framework adopted, social recognition contemplates the redistribution of the material wealth produced and political representation in the decision-making process, insofar as these are irreducible dimensions of justice and should not be subordinated to a superior category of recognition (Fraser, 1997, 2008a). We understand that social justice in relation to migrants and refugees cannot be explained only from the struggle for social recognition, but must also be understood through the struggle for the redistribution of material wealth produced and by equal representation in decision-making spheres. These three forms of struggle correspond to three dimensions of justice: cultural (recognition), political (representation) and economic (redistribution) (Fraser, 2008a). The present study, therefore, is only part of a tripod that needs to be further investigated.

The results found in this research, when analyzed in the light of the theory of social recognition (Faria, 2017; Fraser, 2000, 2002a, 2002b, 2004, 2008a, 2008b; Fraser \& Honneth, 2003), indicate a process of inclusion and recognition of migrants and refugees in Brazilian society that, to some extent, guarantees these individuals and social groups, that is, to this collective subject, access to the material wealth produced. The recognition process is one of the conditions for social inclusion under the criteria of justice (Faria, 2017; Fraser, 2008a).

From a cultural perspective (Fraser, 2008a), regarding social recognition, the results point to a place of exclusion, discrimination and racism for these migrants. We identified prejudice regarding physical condition (color) and xenophobia in relation to cultural aspects and discussed how language is, in this dynamics, an instrument of non-recognition and domination. It is important, however, to understand that prejudice and discrimination are not only merely cultural, as if they were not related to redistribution of material wealth, social recognition, equal representation and the possibilities of these subjects for self-realization.

From a political perspective, regarding equal representation in the decision-making spheres (Fraser, 2008a), the results again point to a place of exclusion. We discussed how migrants are recognized as workers, but not as citizens, that is, although currently in Brazil they can use public services (health, education) free of charge, as well as the national population, and allthough the language itself is a barrier for them to actually use these services, with regard to their participation in decisions that concern them, there is no possibility of representation. The economic, social and cultural rights of refugees are not expressed directly in the law, they still do not have the right to vote, and only recently, in 2017 with the Migrants Law, their rights to participate in social movements without being criminalized have been guaranteed.

In the case of migrants in the city of Curitiba, there are few signs of collective organization with the objective of representing their own interests, we have identified only one specific association of Haitian students, founded by themselves, with support, in the legal procedures, of a Professor of the Law Course from UFPR. There are Brazilian institutions, such as Universitys, churches, NGOs that work to guarantee the rights of this population, but their services, in general, are assistentialist and, even in these spheres, there is little or no space for migrants themselves to take part in decisions about how the activities of these institutions will be developed, taking place only as users of these services. We conclude from the reports here examined that some of these organizations receiving migrants and refugees are dedicated to the monopoly of seduction and the hijacking of subjectivity (Faria, 2017).

From a economic perspective (Fraser, 2008a), regarding the redistribution of material wealth, the results point once again to a place of exclusion. The main difficulty mentioned by the migrants studied here is economic. They report how hard it is to work, find jobs and good jobs. The jobs they find are mostly informal and precarious, developing activities that require low qualification. Even in the case of migrants who have qualifications (training and experience) entering the world of work is difficult. This research identified several institutional and bureaucratic obstacles for migrants to be recognized as professionals in Brazil, such as obstacles in the revalidation of diplomas, re-entenring university, slowness of the process, among others.

Although access to university is a way of guaranteeing the rights of migrants and achieving certain social recognition (Gediel, Friedrich \& Balotin, 2019), this research signals that this entry is not enough to overcome the obstacles constitute for the reproduction of inequalities and the exclusion of this population.

The results of this study points to the precarious inclusion of migrants and refugees in the world of work, showing social injustice and psychological suffering for these subjects. Therefore, the offer of a mass of workers available for international 
exploitation and forced to give up the historic conquests of the working class is indicated. In this way, specialized training for migrants is "replaced by flexible learning, where adaptability and the ability to submit to the new are more important than previous qualification" (Vendramini, 2018, p. 245).

In the process of displacement from one land to another, concrete and subjective references are in suspension - another culture, language, way of sharing symbolic elements and relating to the other is experienced. What is experienced in the field of culture, or in relation to the other (Lacan, 1966), finds no reference in the subjective field. It is, therefore, a displacement not only geographic, but also psychic, an identity that is put to the test in the culture of the other, a culture that is not always inclusive, nor welcoming. Often the absence of references in the field of the other reaffirms for the psychic subject his condition of vulnerability, not only social or concrete, but also psychic. A vulnerability that potentiates suffering and, at its extreme, breaks with the condition of organizing its concrete and subjective life. It is only the recognition of the concrete and subjective experiences of life that allow a human and fair reading of the condition of the forced displaced, refugees and migrants.

In the current discussions on the theory of recognition, it is indicated that the struggle for recognition should not start from the claim of minority or excluded groups, but should understand the processes of exclusion and segregation of the working class. The struggle for recognition occurs in a world of exacerbated material inequality, which means that the challenge of developing a critical theory of society requires an understanding that justice must contemplate the articulation between economic redistribution, social recognition and political representation.

\section{ACKNOWLEDGEMENTS}

We thank Gabriela Loires Diniz Trujillo for the qualified review of the article in English. 


\section{REFERENCES}

Alto Comissariado das Nações Unidas para os Refugiados. (2018). Relatórios de atividades 2018. Brasília, DF: Cátedra Sérgio Vieira de Mello.

Barbosa, L. M. A., \& Ruano, B. P. (2016). Acolhimento, Sentidos e Práticas de ensino de português para migrantes e refugiados, na Universidade de Brasília e na Universidade Federal do Paraná. In J. A. P. Gediel, \& G. G. Godoy (Orgs.), Refúgio e Hospitalidade (pp. 321-336). Curitiba, PR: Kairós.

Bardin, L. (1979). Análise de Conteúdo. Lisboa, Portugal: Edições 70.

Chueiri, V. K., \& Câmara, H. F. (2010). Direitos humanos em movimento: migração, refúgio, saudade e hospitalidade. Revista Direito, Estado e Sociedade, 36, 158-177.

Enriquez, E. (1974). Imaginário social, recalcamento e repressão nas organizações. Tempo Brasileiro, 36/37, 53-94.

Faria, J. H. (2017). Poder, controle e gestão. Curitiba, PR: Juruá.

Fraser, N. (1997). Justice Interruptus: critical reflections on the "post socialist" condition. New York, NY: Routledge.

Fraser, N. (2000). Rethinking Recognition. New Left Review, 3, 107-120.

Fraser, N. A (2002a, outubro). Justiça Social na Globalização: redistribuição, reconhecimento e participação. Revista Crítica de Ciências Sociais, 63, 7-20.

Fraser, N. (2002b). Redistribuição ou Reconhecimento? Classe e status na sociedade contemporânea. Interseções, 4(1), 7-32.

Fraser, N. (2004, December). Recognition, Redistribution and representation in Capitalist Global Society: an interview. Acta Sociologica, 47(4), 274-382.

Fraser, N. (2008a). Escalas de Justicia. Barcelona, España: Herder Editorial. Fraser, N. (2008b). Adding Insult to Injury. London, UK: Verso.

Fraser, N., \& Honneth, A. (2003). Redistribution or Recognition? A political philosophical exchange. London, UK: Verso, 2003.

Gediel, J. A. P., Friedric, T. S., \& Balotin, F. (2019). Public Education and the Welcoming of Migrants and Refugees in a Brazilian University. Widening Participation and Lifelong Learning Review, 21, 235-244, 2019.

Gediel, J. A. P., \& Godoy, G. G. (2016). Refúgio e Hospitalidade. Curitiba, PR: Kairós Edições.

Godoy, A. S. (1995). Pesquisa qualitativa: tipos fundamentais. Revista de Administração de Empresas, 35(3), 20-29.

Hegel, G. F. (2008). Fenomenologia do Espírito. Petrópolis, RJ: Vozes. Honneth, A. (1991). The critique of power: reflective stages in a critical social theory. Cambridge, UK: MIT Press.
Honneth, A. (2007). Sofrimento de Indeterminação. São Paulo, SP: Singular/Esfera Pública.

Honneth, A. (2009). Luta por Reconhecimento: a gramática social dos conflitos sociais. São Paulo, SP: Editora 34.

Lacan, J. (1966). O estádio do espelho como formador da função do eu. In J. Lacan (Ed.), Escritos (pp. 96-103). Rio de Janeiro, RJ: Zahar.

Lei $n^{\circ} 13.445$ de 24 de maio de 2017. (2017). Brasília, DF: Presidência da República. Retrieved from https://www.planalto.gov.br/ccivil_03/_ ato2015-2018/2017/lei/l13445.htm

Lévy, A., Nicolaii, A, Enriquez, E., \& Dubost, J. (1994). Psicossociologia: análise social e intervenção. Petrópolis, RJ: Vozes.

Machado, G. S., Barros, A. F. O., \& Martins Borges, L. (2019, abril). A escuta psicológica como ferramenta de integração: práticas clínicas e sociais em um Centro de Referência de Atendimento a Imigrantes em Santa Catarina. REMHU: Revista Interdisciplinar da Mobilidade Humana, 27(55), 79-96.

MÉSZÁROS, I. (2002). Para Além do Capital. São Paulo, SP: Boitempo.

Ministério da Justiça. (2019). Relatório Refúgio em Números (4a. ed.). Brasília, DF: Author.

Moreira, J. B. (2014). Refugiados no Brasil: reflexões acerca do processo de integração local. REMHU: Revista Interdisciplinar da Mobilidade Humana, 22(43), 85-98.

Moulin, C. (2011). Os direitos humanos dos humanos sem direitos: refugiados e a política do protesto. Revista Brasileira de Ciências Sociais, 26(76), 145-155.

Rosa, M. (2018). Seleção e ingresso de estudantes refugiados no ensino superior brasileiro: a inserção linguística como condição de hspitalidade. Trabalhos em Linguística Aplicada, 57(3), 1534-1551.

Silva, J. P. (2008). Trabalho, Cidadania e Reconhecimento. São Paulo, SP: Annablume.

Taylor, C. (2000). Argumentos Filosóficos. São Paulo, SP: Loyola.

Taylor, C. (2005). As Fontes do Self: a construção da identidade moderna (2a ed.). São Paulo, SP: Loyola.

United NationS Refugee Agency. (2020). Forced Displacement in 2019. Global Trends. Retrieved from https://www.unhcr.org/5ee200e37/\#_ ga=2.235234177.1062887458.1596151489-2128983668.1589915299

Vendramini, C. R. (2018). A categoria migração na perspectiva do materialismo histórico e dialético. Revista Katálysis, 21(2), 239-260.

Zeni, K., \& Filippim, E. S. (2014). Migração haitiana para o Brasil: acolhimento e políticas públicas. Revista Pretexto, 15(2), 11-27. 
José Henrique de Faria

ORCID: https://orcid.org/0000-0003-3971-7992

Ph.D. in Administration from University of São Paulo (FEA-USP); Full professor of the Postgraduate Program in Administration at Federal University of Paraná (PPGADM-UFPR); Visiting Professor of the Postgraduate Program in Administration at Federal Technological University of Paraná (PPGA-UTFPR).

E-mail: jhfaria@gmail.com

Elaine Cristina Schmitt Ragnini

ORCID: https://orcid.org/0000-0002-6086-2388

Ph.D. in Education from Federal University of Paraná (UFPR); Master in Business Administration from Federal University of Paraná (UFPR); Psychologist from Federal University of Paraná (UFPR); Adjunct Professor from Department of Psychology at Federal University of Paraná (DEPSI-UFPR).

E-mail: elaine@ufpr.br

\section{Camila Brüning}

ORCID: https://orcid.org/0000-0003-3869-3917

Ph.D. in Administration from Federal University of Paraná (UFPR); Master in Administration from Federal University of Paraná (UFPR); Psychologist from Federal University of Paraná (UFPR); Adjunct Professor from Department of Psychology at Federal University of Paraná (DEPSI-UFPR); Professor of the Graduate Program in Psychology at Federal University of Paraná (PPGPSI-UFPR). E-mail: camila.bruning@ufpr.br 